\title{
ArcheoSciences
}

Revue d'archéométrie

\section{Dacian bracelets and Transylvanian gold: ancient history and modern analyses}

Bracelets de Dacie et or de Transylvanie : histoire ancienne et analyses modernes

Bogdan Constantinescu, Roxana Bugoi, Viorel Cojocaru, Martin Radtke, Thomas Calligaro, Joseph Salomon, Laurent Pichon, Stefan Röhrs, Daniele Ceccato, Ernest Oberländer-Târnoveanu, Corine Ionescu and Dana Pop

\section{OpenEdition}

\section{Journals}

\section{Electronic version}

URL: http://journals.openedition.org/archeosciences/2234

DOI: 10.4000/archeosciences.2234

ISBN: 978-2-7535-1598-7

ISSN: $2104-3728$

Publisher

Presses universitaires de Rennes

Printed version

Date of publication: 31 December 2009

Number of pages: $221-225$

ISBN: 978-2-7535-1181-1

ISSN: 1960-1360

\section{Electronic reference}

Bogdan Constantinescu, Roxana Bugoi, Viorel Cojocaru, Martin Radtke, Thomas Calligaro, Joseph Salomon, Laurent Pichon, Stefan Röhrs, Daniele Ceccato, Ernest Oberländer-Târnoveanu, Corine Ionescu and Dana Pop, « Dacian bracelets and Transylvanian gold: ancient history and modern analyses », ArcheoSciences [Online], 33 | 2009, Online since 10 December 2012, connection on 19 April 2019. URL : http://journals.openedition.org/archeosciences/2234 ; DOI : 10.4000/ archeosciences.2234 


\title{
Dacian bracelets and Transylvanian gold: ancient history and modern analyses
}

\author{
Bracelets de Dacie et or de Transylvanie : \\ histoire ancienne et analyses modernes
}

\author{
Bogdan Constantinescu*, Roxana Bugoi*, Viorel Cojocaru*, Martin Radtke**, \\ Thomas Calligaro***, Joseph Salomon ${ }^{* * *}$, Laurent Pichon ${ }^{* * *}$, Stefan Röhrs***, \\ Daniele Ceccato****, Ernest Oberländer-TÂrnoveanu*****, \\ Corine IONESCU****** and Dana Por ${ }^{* * * * * * *}$
}

\begin{abstract}
The recovery of the Dacian gold bracelets was the most thrilling archaeological event of the last years in Romania. The artefacts are exhibited in the Historical Treasure section of the National History Museum of Romania, Bucharest, being recovered from the international antique markets through a concerted effort of the Romanian, French, and German authorities.

This paper reviews the X-Ray Fluorescence (XRF) analyses carried out on these exquisite artefacts. These measurements followed the visual examination of qualified experts, which concluded that the gold spiralled bracelets showed strong stylistic similarities with the Dacian silver bracelets discovered until that date in archaeological contexts.

Since the most likely source - for geographical and historical reasons - for the metal used to manufacture these artefacts was the Transylvanian Apuseni mountains, additional measurements on several fragments of natural Transylvanian gold, both from placers and primary deposits, were performed using Synchrotron Radiation X-ray Fluorescence (SR-XRF) at the BESSY synchrotron, Berlin, and micro Particle Induced X-ray Emission (micro-PIXE) at the AGLAE accelerator, Paris, and at the AN2000 accelerator of LNL, Padova.

The conclusion of this study was that the recovered spirals are genuine Dacian artefacts, made by cold hammering, chiselling and punching Transylvanian unrefined gold - gold panned from riverbeds mixed with primary gold, most likely extracted from surface veins.
\end{abstract}

Résumé : La saisie des bracelets en or de Dacie a été un des événements archéologiques les plus remarquables de ces dernières années en Roumanie. Les objets sont exposés dans le Trésor Historique du Musée National d'Histoire de Roumanie, Bucarest, et ont été récupérés du marché international d'antiquités grâce aux efforts concertés des autorités Roumaines, Françaises et Allemandes.

Cet article fait le bilan de l'analyse de ces objets exquis, réalisée par fluorescence à rayons $X$ (FX). Ces mesures suivent l'examen visuel par des experts qualifiés qui ont conclu que les bracelets en or à spirales montrent des similitudes stylistiques fortes avec les bracelets en argent de Dacie découverts en contexte archéologique.

Comme pour des raisons historiques et géographiques la source la plus probable du métal utilisé pour la fabrication de ces objets se trouve dans les Carpates transylvaniens, des mesures complémentaires ont été réalisées sur différents fragments d'or natif de Transylvanie, provenant tant de placers comme de

* Horia Hulubei National Institute for Nuclear Physics and Engineering - Bucharest 077125, Romania.

** BAM Federal Institute for Materials Research and Testing - Berlin D-12489, Germany.

*** Laboratoire de Recherche et de Restauration des Musées de France, CNRS UMR 171 - Palais du Louvre, Paris cedex 01, France.

**** Laboratori Nazionali di Legnaro, Istituto Nazionale di Fisica Nucleare - Padova 35020, Italy.

***** National History Museum of Romania - Bucharest 030026, Romania.

****** Department of Mineralogy, Babeş-Bolyai University - Cluj-Napoca 400084, Romania.

******* Museum of Mineralogy, Babeş-Bolyai University - Cluj-Napoca 400084, Romania. 
gisements primaires, par fluorescence de rayons $X$ avec radiation de synchrotron (SR-XRF) au synchrotron BESSY, à Berlin, et par émission de rayons $X$ induite par particules chargées (micro-PIXE) à l'accélérateur AGLAE, à Paris, et à l'accélérateur AN2000 du LNL à Padoue.

L'étude à permis de conclure que les bracelets en spirale récupérés sont des objets Daciens authentiques, produits par martelage à froid, ciselure et poinçonnage d'or de Transylvanie non affiné - de l'or de rivière obtenu par batée et mélangé avec de l'or primaire, certainement extrait de filons de surface.

Keywords: gold, authentication, provenance, XRF, micro-PIXE, micro SR-XRF

Mots-clés : or, authentification, provenance, FX, micro-PIXE, micro SR-XRF.

\section{INTRODUCTION}

The eleven Dacian gold bracelets recovered until the summer of 2009 are multi-spiralled (5-7 spirals), and weigh from $682 \mathrm{~g}$ up to $1196 \mathrm{~g}$. The spirals feature at both ends zoomorphic protomes, most likely representations of snakeheads, and stylized palmettes (Fig. 1).

The artefacts were found by looting an UNESCO World Heritage archaeological site - Sarmizegetusa Regia, located in the Carpathian Mountains (nowadays Romania), the capital of the Dacian Kingdom during the period between the $1^{\text {st }}$ century $\mathrm{BC}$ and the $1^{\text {st }}$ century $\mathrm{AD}$ (Daicoviciu and Daicoviciu, 1963). The poachers resorted to illegal metal detectors, the bracelets being found buried in several places (most of them being intentionally specially built hideouts) near the sacred precincts of Sarmizegetusa. The artefacts were illegally exported and sold on the antiquity market, being recovered through the concerted efforts of the Romanian, French and German authorities, and with the involvement of the INTERPOL (Lazăr et al., 2008).

To asses their authenticity, the bracelets were visually examined by a group of experts, who decided on stylistic grounds that the artefacts present strong similarities with the Dacian silver bracelets discovered until then in archaeological contexts, and which are exhibited in (or stored in the deposits of) several Romanian and foreign museums. By studying the marks left on the surfaces of the bracelets, it was concluded that the manufacturing techniques used for the spirals were cold hammering, punching and chiselling (Lazăr et al., 2008).

Due to their special shape, decoration and heavy weight, and, not least, to the material they were made of - the fascinating and powerful gold - it was suggested that these artefacts had a tremendous significance for Dacian society, most likely being ritual objects and/or power insignia.

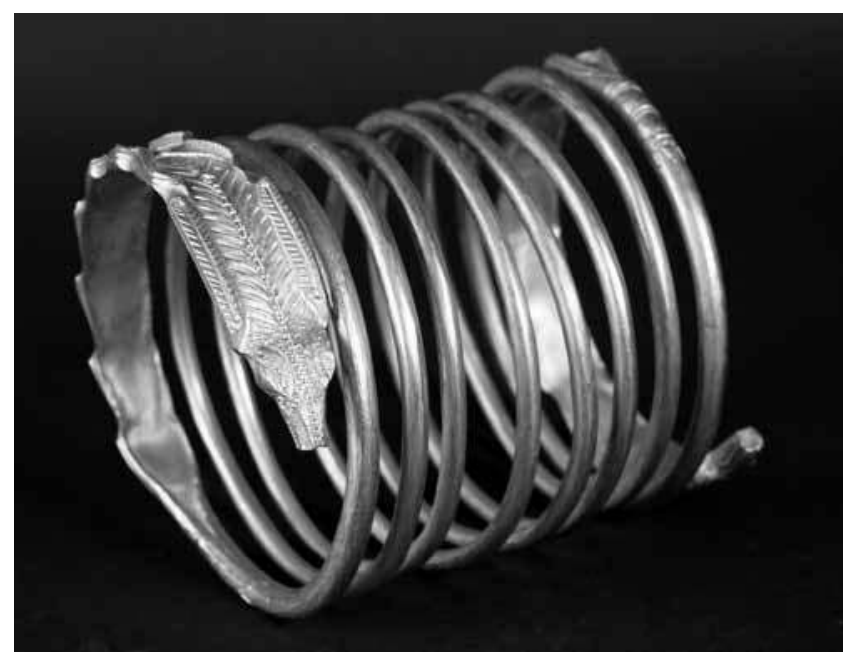

Figure 1: (See colour plate) Bracelet no. 3.

Figure 1: (Voir planche couleur) Bracelet référence 3.

Since the Romanian judicial bodies that investigated the case of poaching an UNESCO World Heritage site required further arguments supporting the authenticity of the bracelets, a compositional analysis of the gold alloy of the spirals was requested. Because only local, non-destructive and noninvasive analyses were allowed, XRF was chosen to provide the details regarding the elemental composition of the artefacts.

Taking into account the wealth of ancient gold artefacts unearthed on the Romanian territory, an extensive study of Transylvanian native gold fragments was performed as well, since this geographical area is known to have been a source for gold exploitation since prehistory (Hauptmann et al., 1995). These investigations started with the gold sources primary and secondary - located closest to the places where the artefacts were found (results reported in Bugoi et al., 2008), and continued with other Transylvanian gold sources (see Neaç̧u et al., 2009). 


\section{MethodS}

The XRF compositional analysis of the bracelets was performed using a setup based on a ${ }^{241} \mathrm{Am}(30 \mathrm{mCi})$ annular radioactive source and a $\mathrm{Si}(\mathrm{Li})$ horizontal detector - see the XRF spectrum shown in Figure 2.

The micro-PIXE measurements carried out on Transylvanian native gold samples were performed both in air with a $3 \mathrm{MeV}$ proton micro-beam $\left(50 \times 50 \mu \mathrm{m}^{2}\right)$ at the AGLAE accelerator in Paris, and in vacuum with a $2 \mathrm{MeV}$ proton beam $\left(4 \times 4 \mu \mathrm{m}^{2}\right)$ at the AN2000 accelerator of the LNL, INFN, Padova.

The micro SR-XRF analyses of another set of Transylvanian geological gold samples were performed at the BESSY synchrotron, Berlin, in air, the characteristic X-rays being excited with a $34 \mathrm{keV}$ monochromatic X-ray beam $\left(100 \times 200 \mu \mathrm{m}^{2}\right)$.

The detailed description of the employed experimental setups, as well as the previously reported results, can be found in Bugoi et al. (2008) and Constantinescu et al. (2008).

\section{RESULTS AND DISCUSSION}

The results of the XRF analyses obtained for each bracelet are provided in Table 1. It can be easily observed that the spirals contain large amounts of silver (11\% on average) and very small amounts of copper ( $0.9 \%$ on average). This compositional pattern is consistent with the one of natural gold, which contains up to $40 \%$ silver and up to $1 \%$ copper (Guerra, 2000; Tylecote, 1987).

Obviously, there was no intention to refine the gold employed to manufacture these artefacts. Presumably, different gold ingots were used to manufacture the bracelets, an aspect suggested by the slight differences in the compositions of the eleven artefacts.

Traces of Sn were observed in the XRF spectra - see Figure 2 and Table 1. Most likely, the $\mathrm{Sn}$ originates from the first melting in reducing atmosphere of alluvial gold, in which cassiterite $\left(\mathrm{SnO}_{2}\right)$ grains were present (Dube, 2006; Guerra and Calligaro, 2003).

The composition of bracelet no. 8, with the highest Sn and $\mathrm{Cu}$ content of all the investigated armbands, points towards a hypothesised tin-bronze alloying of the gold ingot used to manufacture this object (Dube, 2006).

$\mathrm{Ca}, \mathrm{Ti}, \mathrm{Mn}, \mathrm{Fe}$, and $\mathrm{Ba}$ traces, most likely from soil contamination (the artefacts were supposedly buried for two thousand years), were detected on almost all bracelet surfaces. $\mathrm{Sb}$ traces were also detected in some bracelets, pointing towards the use of a primary deposit gold source.

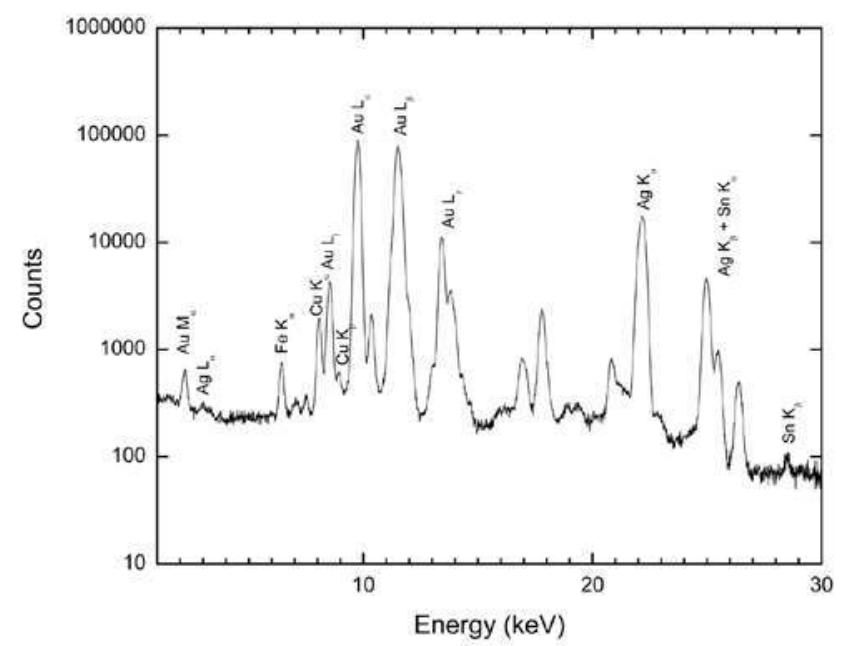

Figure 2: XRF spectrum of bracelet no. 11. Figure 2 : Spectre FX du bracelet référence 11

\begin{tabular}{|c|c|c|c|c|}
\hline Bracelet no. & $\mathrm{Au}(\mathrm{wt} \%)$ & $\mathrm{Ag}(\mathrm{wt} \%)$ & $\mathrm{Cu}(\mathrm{wt} \%)$ & $\mathrm{Sn}(\mathrm{mg} / \mathrm{kg})$ \\
\hline 1 & 89.8 & 9.5 & 0.6 & 200 \\
\hline 2 & 78.2 & 20.3 & 1.5 & 60 \\
\hline 3 & 82.4 & 16.2 & 1.4 & 360 \\
\hline 4 & 91.5 & 8.1 & 0.4 & 125 \\
\hline 5 & 92.8 & 6.9 & 0.3 & $<\mathrm{MDL}$ \\
\hline 6 & 92.0 & 7.1 & 0.9 & 230 \\
\hline 7 & 92.9 & 6.3 & 0.7 & $<\mathrm{MDL}$ \\
\hline 8 & 85.0 & 12.8 & 2.1 & 1500 \\
\hline 9 & 87.1 & 12.2 & 0.6 & 120 \\
\hline 10 & 87.1 & 11.8 & 0.7 & 425 \\
\hline 11 & 86.1 & 12.6 & 0.7 & 400 \\
\hline
\end{tabular}

Table 1: XRF concentrations of the Dacian gold bracelets (the overall relative uncertainty is estimated to be $-1 \%$ for Au concentrations, $-10 \%$ for $\mathrm{Ag}$ and $\mathrm{Cu}$ concentrations and $-20 \%$ for $\mathrm{Sn}$ concentrations).

Tableau 1 : Compositions obtenues par XRF des bracelets en or Daciens (incertitudes relatives moyennes sont estimées à $-1 \%$ pour les teneurs en $\mathrm{Au},-10 \%$ pour les teneurs en $\mathrm{Ag}$ et en $\mathrm{Cu}$ et $-20 \%$ pour les teneurs en $S n$ ).

Both micro-PIXE and micro SR-XRF led to the following conclusions: Transylvanian gold, both placer and primary, contains high and variable amounts of $\mathrm{Ag}$ (from $8 \%$ up to $35 \%$ ), low amounts of $\mathrm{Cu}$ (hundreds of $\mathrm{mg} / \mathrm{kg}$ on average, but up to $1.5 \%)$, traces of $\mathrm{Sn}$ for placer gold $(500 \mathrm{mg} / \mathrm{kg}$ on average), and traces of $\mathrm{Sb}$ (up to $900 \mathrm{mg} / \mathrm{kg}$ ) and Te (up to $3000 \mathrm{mg} / \mathrm{kg}$ ) for primary gold.

These results are in agreement with the geochemical data for Transylvanian gold from Berbeleac (1985) and Tămaş et al. (2006). They also confirm the previously published data, showing that Transylvanian primary gold is characterized by relatively large $\mathrm{Ag}$ amounts (more than $10 \%$ on average, but more often $20 \%$ or even $30 \%$ ) (Tylecote, 1987; Hauptmann 
et al., 1995; Bugoi et al., 2008 and references therein). The amount of Ag is generally lower for the Transylvanian gold samples of alluvial origin, an aspect explained through the weathering of the gold particles, $\mathrm{Ag}$ and $\mathrm{Cu}$ being more susceptible to dissolution or leaching, depending on the $\mathrm{pH}$ of the surrounding environment (Dube, 2006).

The native gold samples turned out to be very inhomogeneous, an aspect highlighted by employing the scanning option of these micro-analytical techniques. From a methodological point of view, it is worth mentioning that the sensitivity of micro SR-XRF is significantly superior to the one of micro-PIXE, especially for Sn detection.

The $\mathrm{Cu}$ content of the bracelets was slightly higher than the one of the natural gold samples. This was most likely due to the melting of the accompanying gold minerals, which leads to an 'enrichment' in terms of $\mathrm{Cu}$ content in the finite objects (Hauptmann et al., 1995).

By comparing the XRF results of the bracelets with the micro-PIXE and micro SR-XRF results of Transylvanian gold samples, the determined trace elements and the overall compositional pattern, it was concluded that, most likely, the Dacian gold bracelets were made from unrefined Transylvanian native gold - natural panned gold (gold that has not been deliberately alloyed or purified) mixed with primary gold, using a primitive metallurgy. Thus, in addition to the stylistic and historical arguments, the XRF analyses further supported the authenticity of the Dacian bracelets.

\section{Conclusions}

The recovery and investigation of the Dacian gold bracelets is a good example of the close cooperation between the judicial and police bodies, archaeologists, cultural heritage experts, physicists and geologists. Despite their turbulent recent history, these gorgeous artefacts finally found their peace, allowing themselves to be admired in their shining splendour in the showcases of the Historical Treasury of the National History Museum of Romania in Bucharest.

The elemental analyses carried out by means of X-ray methods played an important role in the authentication of these artefacts. Taking into account the location where the bracelets were found, the historical arguments about the Dacian civilization, and, not least, the results of the elemental analyses undertaken both on natural gold samples and on the recovered artefacts, it was concluded that, most likely, natural panned gold (gold that has not been deliberately alloyed or purified) mixed with primary gold from Transylvania was used to manufacture the Dacian spiralled bracelets.

\section{Acknowledgements}

The financial support of the EU-ARTECH project (allowing access to the AGLAE accelerator, Paris), of the EU FP6 contract EURONS no. RII3-CT-2004-506065 (granting access to the AN2000 LNL accelerator, Padova) and of EU FPG contract no. RII3-CT-2004-506008 (funding the experiment at the BESSY synchrotron, Berlin) are gratefully acknowledged.

\section{References}

Berbeleac, I., 1985. Zăcăminte de aur. Bucureşti, Editura Tehnică (in Romanian).

Bugoi, R., Cojocaru, V., Constantinescu, B., Calligaro, T., Pichon, L., Röhrs, S. and Salomon, J., 2008. Compositional studies on Transylvanian gold nuggets: Advantages and limitations of PIXE-PIGE analysis. Nuclear Instruments and Methods in Physics Research B 266(10): 2316 -2319.

Constantinescu, B., Bugoi, R., Cojocaru, V., Radtke, M., Calligaro, T., Salomon, J., Pichon, L., Röhrs, S., Ceccato, D. and OBErländer-TÂrnoveanu, E., 2008. Micro SR-XRF and micro-PIXE studies for archaeological gold identification - the case of Carpathian (Transylvanian) gold and of Dacian bracelets. Nuclear Instruments and Methods in Physics Research B 266(10): 2325-2328.

Daicoviciu, C. and Daicoviciu, H., 1963. Sarmizegethusa: les citadelles et les agglomerations daciques des Monts d'Oraştie. Bucureşti, Ed. Meridiane (in French).

DuBE, R.K., 2006. Interrelation between gold and tin: A historical perspective. Gold Bulletin 39(3): 103-113.

Guerra, M.F., 2000. The study of the characterisation and provenance of coins and other metal work using XRF, PIXE and Activation Analysis, in D.C. Creagh, D.A. Bradley (eds), Radiation in Art and Archeometry. Amsterdam: Elsevier, 378-416.

Guerra, M.F. and Calligaro, T., 2003. Gold cultural heritage objects: a review of studies of provenance and manufacturing technologies. Measurement Science and Technology 14: 15271537.

Hauptmann, A., Rehren, Th. and Pernicka, E., 1995. The composition of gold from the ancient mining district of Verespatak/ Roşia Montană, România, in G. Morteani, J.P. Northover (eds.), Prehistoric Gold in Europe - Mines, Metallurgy and Manufacture. Berlin, Springer Verlag, 369-381.

Lazăr, A., Deppert-Lippitz, B. and Ferri, P.G. (eds.), 2008. Combating the criminality against the European archaeological heritage. Bucureşti, Lumina Lex Publishing House.

Neacşu, A., Popescu, G.C., Constantinescu, B., Vasilescu, A. and CEсCATo, D., 2009. The geochemical signature of native gold from Roşia Montană and Musariu ore deposits, Metaliferi 
Mts. (Romania); Preliminary Data. Carpathian Journal of Earth and Environmental Sciences 4(1): 49-59.

Tămaş, C., Bailly, L., Ghergari, L., O’Connor, G. and Minuț, A., 2006. New occurrences of tellurides and argyrodite in Roşia Montană, Apuseni Mts., Romania, and their metallogenetic significance. The Canadian Mineralogist 44(2): 367383.
Tylecote, R.H., 1987. The early history of metallurgy in Europe. London and New York, Longman. 
